\title{
TAX SUPPORT EVALUATION FOR R\&D ACTIVITIES OF COMPANIES
}

\author{
Martina CERNIKOVA (D, Sarka HYBLEROVA (D) \\ Faculty of Economics, Technical University of Liberec, Liberec, Czech Republic
}

Received 18 January 2021; accepted 01 May 2021

\begin{abstract}
The article evaluates the impact of tax support for $R \& D$ on the volume of $R \& D$ outputs generated by companies. The number of patent applications was chosen as the R\&D metric for business output. Both linear dependence using linear regression and non-linear dependence using decision trees were used within the research. The significance of indirect support in the context of other sources of funding R\&D activities of companies was primarily assessed. The dependence of the number of patent applications on individual sources of financing of the Business Enterprise Expenditure on R\&D was examined. Even after scaling variables, the research in the period under review confirmed the strongest dependence between the number of patent applications and the financial resources provided by the Business enterprise sector for all countries surveyed. Subsequently, the model reduced by the impact of Business enterprise sector resources was created. Of the three remaining variables considered, the analysis showed the strongest dependence of the number of patent applications on the amount of indirect support. The research points to the fact that impact of tax support on the volume of relevant $R \& D$ outputs is relatively significant.
\end{abstract}

Keywords: tax incentives, corporate income tax, support for R\&D, indirect support, patent applications, linear regression.

JEL Classification: $\mathrm{H} 25, \mathrm{O} 32$.

\section{Introduction}

Our society is currently facing new challenges related to dynamic changes in traditional ways of creating added value, demographic trends, climate change and social change. These new challenges need to be addressed by both innovative and research strategies of individual countries and multinational clusters. For this reason, considerable public and private funds are spent in support of research and development in all developed countries. The Organization for Economic Co-operation and Development (OECD) published the so-called Frascati manual (hereinafter, FM) in 1963 following an expert meeting in the field of research and development statistics. This is a document intended for the evaluation of scientific and

${ }^{\star}$ Corresponding author. E-mail: sarka.hyblerova@tul.cz

Copyright (c) 2021 The Author(s). Published by Vilnius Gediminas Technical University

This is an Open Access article distributed under the terms of the Creative Commons Attribution License (http://creativecommons. org/licenses/by/4.0/), which permits unrestricted use, distribution, and reproduction in any medium, provided the original author and source are credited. 
technical activities. It is not only a methodological aid, but also a tool for statistical analysis and collection of information on realized activities in the area of research, development and innovation. Research and experimental development (R\&D), according to the current version of FM (from 2015), consists of creative and systematic work carried out to increase the level of knowledge - including knowledge of humanity, culture and society - and to propose new ways of applying available knowledge. The term R\&D includes not only basic applied research, but also experimental development. In accordance with the requirements of FM, the criteria of novelty, creativity, systematic character, uncertainty and reproducibility should be met when creating R\&D output.

To support R\&D, each country selects appropriate instruments of direct and indirect support, taking into account a variety of factors. The idea is to accelerate economic growth and increase the competitiveness of the economy. If direct support is represented by grant titles usually corresponding to the country's innovation strategies, then indirect support is implemented in the corporate environment in the form of tax support. Advantages and disadvantages of direct and indirect support are currently widely discussed by the professional public and their effectiveness is examined. In recent years, substitution has occurred between direct and indirect support in a number of countries, and business entities have accentuated the use of indirect support. There are a number of methodological guidelines on how to assess the effectiveness of the indirect support use, but it is relatively difficult to find an objective tool for its evaluation or international comparison.

The research focused primarily on the issue of indirect support of R\&D activities of companies. The aim was to find out how significant is the impact of indirect support on the volume of relevant R\&D outputs generated by companies. The impact of other support instruments (especially investments of companies' own resources in the area of R\&D) was analyzed. On the basis of a detailed examination of the issue, the number of patent applications was chosen as an adequate metric of R\&D outputs. The study was based on data reported by selected economies from around the world and published by the OECD. The model developed examined the dependence of the number of patent applications on individual sources of financing of the Business enterprise expenditure on R\&D (BERD), including indirect support. Both linear dependence using linear regression and nonlinear dependence using decision trees were used for our investigation.

\section{Literature review}

Expenditure on research and development is an important indicator of innovation activity of companies (Akis, 2015). The importance of innovation for the development of society is obvious. Schumpeter (1934) not only created this term, but linked innovation creation with entrepreneurs and economic growth. In his later articles, he accentuates the importance of large companies with sufficient capital to carry out and finance their own research and development (Schumpeter, 1954). The hypothesis of linking companies with innovation and economic growth has been confirmed by a number of authors (e.g. Bronzini \& Iachini, 2014; Pisár et al., 2020) and is now fully respected. At present, the expert polemics focuses more 
on the area of R\&D financing and efficiency of use of individual sources. R\&D can generally be financed either from public or private sources (Carboni, 2011).

According to (Griliches, 2000), market failure can be an argument for the need of public support of private companies. Knowledge (obtained from R\&D) shows the characteristics of public goods and their effect (positive externalities) must be supported for social development (Bloom et al., 2013). Externalities connected with knowledge transfer were identified by Nelson (1959) in academic research primarily funded from public sources, and later recognized in companies. The failure of the R\&D market may also be due to a certain asymmetry of information between innovators and investors (innovators protect innovation information and investors cannot properly assess the intended investment) (Edler et al., 2012). Over the years, arguments for the support of R\&D from public sources have been increasing (Lundvall \& Borrás, 2009), as R\&D is not only isolated in one company, but is influenced by the state of the economy and the country's priorities in R\&D (Einiö, 2014). However, the use of public support also carries a risk of failure when distributing it. In order to eliminate these failures, the EU created a methodological tool for the area of state support (European Union [EU], 2014) which was also implemented as a recommendation material by the Ministry of Regional Development of the Czech Republic (2018).

National governments are looking for an optimal mix of instruments to support private R\&D investment. State support for private R\&D is provided directly or indirectly (Ernst et al., 2014). Direct support is provided through grants (for a specific research project). Indirect support is realized with the help of selected tax incentives (usually in the form of discounts, exemptions, deductions, accelerated depreciation, or so-called patent boxes) (Westmore, 2013). The advantage of direct government support is its relatively bigger transparency. The recipient of support, purpose and conditions of granting and, where applicable, enforceability are clearly identified. According to (Bernanke, 2011), direct government support for R\&D is particularly suitable for large-scale scientific projects with a fixed timeframe and for projects that are needed but unattractive on the market (Calvino et al., 2016). According to Mohnen (Lokshin \& Mohnen, 2013), direct R\&D support is more suitable for companies with limited access to capital resources. Direct support also allows better control by state authorities and can be used to maintain R\&D even in times of economic recession.

Indirect support for private $\mathrm{R} \& \mathrm{D}$ in the form of tax incentives is broad-based and allows $\mathrm{R} \& \mathrm{D}$ to be supported across many disciplines and projects by reducing $\mathrm{R} \& \mathrm{D}$ costs for a large number of companies. Practically every company can obtain indirect support if the specified conditions are met. It is generally seen as a valuable incentive to realize R\&D in small firms that may have trouble getting subsidies (Neubig et al., 2016). Indirect tax support allows the distribution of R\&D investments more according to the needs of the company (application in the market, generating profit) however, it may not be fully in line with the innovative government strategy. A significant disadvantage of indirect support for development research is also their more complex implementation. The creation of effective indirect tax support for research and development places higher demands on the sophistication of the whole project due to the impact on the country's tax system (Toledano et al., 2016).

Governments of developed countries are increasingly using R\&D tax incentives in an effort to eliminate the potential effects of the economic crisis. Thanks to investments in $R \& D$, 
these incentives should support competitiveness, productivity and hence economic growth of individual countries. R\&D tax incentives are used not only by the EU or the US, but also by many other market economies including Japan, Brazil, China, India and South Africa.

The extent of use of indirect support varies from country to country. In some countries, tax support is less used because tax incentives are dealt with at federal level, but direct subsidies remain within the competence of regions or local communities (Nauwelaers, 2016). In several EU countries, tax incentives are not offered at all, however, in these countries there is a recurring debate on their possible introduction. These are currently Germany, Estonia and Sweden (Pfeiffer \& Spengel, 2017).

Although tax incentives are common in developed countries, they are far from homogeneous, are fundamentally different, and a mix of instruments is mostly used. Most incentives are based on the corporate tax law, although in some countries these incentives apply to social security payments or affect payroll taxes. Table 1 below illustrates the group division of frequencies by type of R\&D tax support in the EU.

It is clear from Table 1 that the design of indirect $\mathrm{R} \& \mathrm{D}$ support is based on individual provisions of corporate income tax, to a lesser extent on other provisions (personal income tax, or other legislation). The most widely used are tax incentives in the form of an expensebased incentive, and enhanced allowance or the use of patent box is also widespread. R\&D tax incentives are becoming increasingly popular for various reasons, such as their administrative simplicity, neutrality and the provision of fair conditions (Ognyanova, 2017). Although patent boxes are widely used as a tax incentive, some evidence suggests that patent boxes do not directly influence R\&D development (Klemens, 2016), but rather they are used as a tax optimization tool (Griffith et al., 2014).

In the Czech Republic, only one instrument of indirect $\mathrm{R} \& \mathrm{D}$ support is used in the form of a deductible item from the tax base pursuant to Section 34 (4) and (5) of Act No. 586/1992 Coll., on Income Taxes (hereinafter ITA). The formulation of indirect public support of R\&D has not been in ITA since its inception. It was only implemented with effect from 1 January 2005. Later partial amendments clarified the conditions for the application of this deduction; it was defined what can be considered as R\&D from the point of view of indirect support (or a list of expenditures that can be applied as R\&D expenditure). In 2014, there were more pos-

Table 1. Design of R\&D tax support in the EU - group division of frequencies (source: author's own processing, data source Ognyanova, 2017)

\begin{tabular}{|l|l|c|c|c|c|c|}
\hline \multicolumn{2}{|c|}{} & \multicolumn{5}{|c|}{ Type of R\&D tax support } \\
\cline { 2 - 7 } & \multicolumn{5}{|c|}{ Expense-based } & Input-based \\
\cline { 2 - 7 } & $\begin{array}{c}\text { Tax } \\
\text { credits }\end{array}$ & $\begin{array}{c}\text { Enhanced } \\
\text { allowance }\end{array}$ & $\begin{array}{c}\text { Accelerated } \\
\text { depreciation }\end{array}$ & $\begin{array}{c}\text { Existing } \\
\text { expense-based }\end{array}$ & $\begin{array}{c}\text { Patent } \\
\text { box }\end{array}$ \\
\hline \multirow{2}{*}{$\begin{array}{l}\text { Type of } \\
\text { tax }\end{array}$} & $\begin{array}{l}\text { Corporate } \\
\text { income tax }\end{array}$ & 14 & 15 & 10 & 23 & 13 \\
\cline { 2 - 7 } & $\begin{array}{l}\text { Personal } \\
\text { income tax }\end{array}$ & 4 & 3 & 2 & 5 & 3 \\
\cline { 2 - 7 } & $\begin{array}{l}\text { Other } \\
\text { legislation }\end{array}$ & 5 & 3 & 1 & 6 & 5 \\
\hline
\end{tabular}


sibilities to include research and development costs into a group of eligible costs in the Czech Republic. Since then, the law has also allowed to include the costs of services and intangible results of research and development which are acquired from a public university or research organization and are related to the implementation of the $\mathrm{R} \& \mathrm{D}$ project.

Although R\&D intensity in the Czech Republic is still slightly below the European Union average (Eurostat, 2019), Czech R\&D expenditures are growing and the use of indirect support in the form of tax relief has been gradually increasing in the past. A turning point occurred in 2016 when the use of this tool decreased according to information from the Czech Statistical Office (2019). This was due to an increase in the uncertainty of companies in relation to the assessment of tax deductions by financial or other authorities. There were frequent uncertainties and penalties on the part of the supervisory body when checking the use of this deduction. Delloite (2018) the improvement should be brought about by the amendment of the partial legislative provisions of April 2019 (ITA).

The use of indirect R\&D support in the economic environment of individual countries generates certain positives and negatives (as well as any other R\&D support) (Drabkova, 2017). The advantages may be easier use of the indirect incentive for the company, lower administrative costs. The private sector can decide what is the most productive way to incent, the risk of problematic tendering is eliminated. The disadvantage is, on the other hand, worse control of the use of funds, support for projects with a low innovation value, indirect link to the country's innovation strategies, Risk of firms relabeling other activities as R\&D (Köhler et al., 2012).

Different design elements of private research tax support make the generosity of this support significantly different from one OECD country to another. The so-called B-index is used for international comparison of this support (Warda, 2001). Although it is a useful analytical and benchmarking tool, it should be noted that the calculation of this index is based on a number of methodological assumptions (OECD, 2013). The B-index is calculated as:

$$
\text { B-index }=(1-A) /(1-T) \text {. }
$$

In this expression, $T$ is the corporate tax rate and $A$ is the combined net present value of allowances and credits applying to R\&D outlays. Thus, the B-index expresses the present value of pre-tax revenue required to cover initial $R \& D$ investment and corporate income tax payments in order to make it profitable to realize this $\mathrm{R} \& \mathrm{D}$. The lower the $\mathrm{B}$-index value, the more generous the country has indirect tax support for $\mathrm{R} \& \mathrm{D}$. A level $1 \mathrm{~B}$-index means that the tax system is neutral to the support of R\&D. In the long run, Spain has had the lowest indicator from the OECD countries (Guellec \& van Pottelsberghe de la Potterie, 2003).

The importance and effect of tax support is currently being discussed by the general public. The vast majority of empirical studies confirms that tax incentives are effective for stimulating business R\&D expenditure. Ernst and Spengel (2011) came to the same conclusion. The effectiveness of these incentives is influenced by the overall design and their implementation in the economic environment (Castellacci \& Lie, 2015). There is a general consensus among experts that efficient management of the use of tax incentives, together with their optimal settings, can support the achievement of strategic $R \& D$ objectives and innovation processes in a particular country. 
An important indicator of the effectiveness of the use of tax support (or other financial resources spent on $R \& D$ support) is the number of patents, or the number of patent applications. A high correlation between the number of patents and R\&D performance has been proved de Rassenfosse and van Pottelsberghe de la Potterie (2011). According to an OECD study (Skeie et al., 2017) the number of patent applications (as opposed to the number of patents) has higher informative value. The number of patents does not reflect all research, innovative or financial efforts since many $\mathrm{R} \& \mathrm{D}$ outputs do not successfully complete the patent process for various reasons. Using the number of patents or patent applications is associated with certain risks and inaccuracies. In many countries, the number of patents and patent applications is more or less influenced by patent offshoring (these are mainly small open economies with a relatively high share of foreign capital). For example, the Czech Republic has been showing a patent offshoring rate of about $20 \%$ in recent years with an increasing trend Technology Agency of the Czech Republic (2019). By contrast, economies such as Germany show an offshoring rate of around 7\% in patent activity. According to an OECD study (Skeie et al., 2017), the territorial placement of patent activity is also affected by the different tax burden and the level of fees for handling intellectual property. Despite the above risks, however, the number of patents, or the number of patent applications, is considered to be a suitable statistical indicator of the scientific and research activities of individual subjects (OECD, 2009).

\section{Methodology}

The aim of the research was to find out whether indirect support of R\&D has a significant impact on the volume of outputs generated by $R \& D$ activities of companies, by identifying the dependence of the number of patent applications on the sources of $R \& D$ financing of business activities. The number of patent applications was chosen as a measure of outputs. The data reported by economies and published by OECD were used for further research and investigation. These data guarantee the possibility of international comparisons as the surveys in individual economies respect the OECD methodological principles set out in the Frascati Manual (OECD, 2015) and Commission Implementing Regulation (EU) No. 995/2012 of 26 October 2012. In particular, the Tax Support database for R\&D and Innovation was utilized. It was created in November 2018 and integrated into OECD Corporate Tax Statistics. This database contains up-to-date estimates of government tax relief for R\&D tax expenditure in selected economies since 2000. In our research, data for the period of 2000-2016 were used, although for some economies data for 2017 and 2018 are also available; however, for many economies these data are still missing (August 2019). These were the data of 36 economies from around the world (25 European economies, as well as the USA, Canada, Australia, Japan and others) for which an internationally comparable time series of data was available.

The study examined the dependence of the number of patent applications on individual sources of funding for the Business Enterprise Expenditure on R\&D (BERD). BERD funding sources have been classified in compliance with the Frascati Manual 2015 according to the sector where the funds originate:

- Business enterprise sector which includes, inter alia, R\&D tax incentives;

- Government sector which is the provider of direct support of R\&D; 
- Higer education sector;

- Private non-profit sector;

- Rest of World. Within this category of financial resources, EU institutions and other bodies are a major provider of capital for EU businesses.

The research focused on resources provided by the Business enterprise sector, resources provided by the Government sector (direct support of R\&D) and Rest of world. The amount of funding from the Higher education sector and the Private non-profit sector is insignificant to our research. For the research purposes, the reported data on the amount of financial resources spent on $R \& D$ in the Business enterprise sector were adjusted for the amount of indirect R\&D support, which was monitored separately. Furthermore, in the article the term "resources provided / spent by the Business enterprise sector" means these resources adjusted for indirect $\mathrm{R} \& \mathrm{D}$ support.

The dependence of the number of patent applications on the sources of R\&D financing of business activities was investigated both by linear method, using linear regression, and non-linear method, for which decision trees were used. For these purposes, the time series of the number of patent applications was postponed (delayed) by 3 years compared to the time when the financial resources were spent on financing $R \& D$ activities. The three-year shift was chosen with respect to the length of the procedure for obtaining a patent. According to information from the Industrial Property Office of the Czech Republic and the European Patent Organization, it ranges from the moment of filing the application to obtaining a patent of about 3 years minimum.

Indisputable advantage of the regression models used in the investigation of the abovedescribed dependencies for this analysis is the ability to capture dependencies between variables and the strength of these dependencies regardless of their scale. Two models were used to determine the degree of dependency between the various sources of BERD funding and the number of patent applications: linear regression (to capture linear dependence) and decision tree (to capture possible other types of dependencies).

\section{Empirical results and discussion}

According to the methodology described above, a matrix showing correlations between individual variables was elaborated, see Table 2.

Table 2. Matrices showing correlations between individual variables

\begin{tabular}{|l|c|c|c|c|c|}
\hline \multicolumn{1}{|c|}{ Index } & $\begin{array}{c}\text { Indirect } \\
\text { support }\end{array}$ & $\begin{array}{c}\text { Governmet } \\
\text { sector }\end{array}$ & $\begin{array}{c}\text { Business } \\
\text { enterprise sector }\end{array}$ & $\begin{array}{c}\text { Rest of } \\
\text { Word }\end{array}$ & $\begin{array}{c}\text { Number of patent } \\
\text { applications }\end{array}$ \\
\hline Tax incentives & 1 & 0.602 & 0.792 & 0.527 & 0.717 \\
\hline Government sector & 0.602 & 1 & 0.719 & 0.744 & 0.589 \\
\hline $\begin{array}{l}\text { Business enterprise } \\
\text { sector }\end{array}$ & 0.792 & 0.719 & 1 & 0.472 & 0.950 \\
\hline Rest of word & 0.527 & 0.744 & 0.472 & 1 & 0.412 \\
\hline $\begin{array}{l}\text { Number of patent } \\
\text { applications }\end{array}$ & 0.717 & 0.589 & 0.950 & 0.412 & 1 \\
\hline
\end{tabular}


It can be seen from the correlations found that the strongest linear dependency (when considering the individual sources of BERD funding only) is between the number of patent applications and the resources provided by the Business enterprise sector. However, all considered sources of BERD funding show a high positive correlation with the number of patent applications. For the performed analysis, all assessed types of BERD funding sources were transformed into the same scale. For this, the most commonly used Standard Scaler was used, that is scaling to zero mean and unit variance; thus, the corresponding variable $Y$ as $Y=(X-m) / s^{2}$ was created from variable $X$, where $m$ is the mean of $X$ and $s^{2}$ is its variance. Regression approaches were also used to determine which of the BERD funding sources most affected the number of patent applications in combination with others. For linear regression, the equation has the following form

$$
Y=b_{0}+b_{1} I+b_{2} D+b_{3} B+b_{4} W
$$

where: the letters $b i$ denote linear regression coefficients, $I$ denotes the indirect support variable, $D$ direct support, $B$ business enterprise sector, and $W$ Rest of World. The degree of dependence in a model is determined in two ways: based on the coefficient of determination and the significance of variables. For linear regression, the significance of the variables was tested by default using the $t$-test with the null hypothesis $\mathrm{H} 0: b i=0$. The significance was then determined using the $p$-values of this test. For $p$-val $<\alpha$, the null hypothesis at the significance level $\alpha$ is rejected (5\% significance level was used). The results of the $t$-test are presented in Table 3.

It follows from Table 3 that for all tested variables (at the significance level $\alpha=0.1$ ) the null hypothesis that the relevant coefficient is zero based on $p$-values was rejected. Thus, all variables appear to be statistically significant. Note: at the level of $\alpha=0.05$, the Rest of World variable can be described as insignificant.

For the decision tree, the feature importance was used to determine the significance, which was calculated for the given variable as $I=G-G_{l e f t}-G_{\text {right }}$, where $G$ is the gini criterion value in the parent node, $G_{\text {left }}$ and $G_{\text {right }}$ are gini criterion values after the distribution. Significance by the coefficient of determination was calculated as $V_{i}=1-R_{i}$, where $R_{i}$ is the coefficient of model determination where the $i$-th variable is omitted. The results of the decision tree method are presented in Table 4.

It is clear from Table 4 that the strongest dependence appears between the number of patent applications and the resources of the Business enterprise sector. Due to p-values and feature importance, this dependency is significantly more dominant than others. However, it is apparent from the results obtained from the coefficients of determination that all combinations of models (i.e. omitting one of the variables) have great predictive power.

Table 3. Linear regression - $t$-test results (source: author's own; scikit-learn library for Python 3.6; linear_model.linearRegression)

\begin{tabular}{|l|c|c|c|c|}
\hline \multicolumn{1}{|c|}{ Variable $i$} & Indirect support & Government sector & Business enterprise sector & Rest of World \\
\hline$p$-value & $4.930718 \mathrm{e}-21$ & $7.508111 \mathrm{e}-12$ & $1.821603 \mathrm{e}-72$ & $7.087606 \mathrm{e}-02$ \\
\hline Significance $V_{i}$ & 0.0223 & 0.0278 & 0.1311 & 0.0228 \\
\hline
\end{tabular}


Table 4. Decision tree - results (source: author's own; scikit-learn library for Python 3.6; linear_model. linearRegression)

\begin{tabular}{|l|c|c|c|c|}
\hline \multicolumn{1}{|c|}{ Variable $i$} & $\begin{array}{c}\text { Indirect } \\
\text { support }\end{array}$ & $\begin{array}{c}\text { Government } \\
\text { sector }\end{array}$ & $\begin{array}{c}\text { Business } \\
\text { enterprise sector }\end{array}$ & $\begin{array}{c}\text { Rest } \\
\text { of World }\end{array}$ \\
\hline Feat. importance & 0.0106 & 0.0409 & 0.9156 & 0.0326 \\
\hline Significance $V_{i}$ & 0.00247 & 0.0031 & 0.0097 & 0.0039 \\
\hline
\end{tabular}

The linear dependence between the number of patent applications and Business enterprise sector resources is also demonstrated in Figure 1.

The above-mentioned strong dependence of the number of patent applications on the amount of resources of the Business enterprise sector can be seen from Figure 1. The following Figure 2 shows its structure for a more trained decision tree.

In Figure 2, the variables $X[0], X[1], X[2], X[3]$ indicate one after another direct support, indirect support, Business enterprise sector and Rest of World. The first and second layer are all given only by the variable "Business enterprise sector". In the third layer, the indirect support variable is already reflected. The influence of the remaining variables is captured in the fourth layer of the decision tree.

The next step of the research was to create a model reduced by the impact of Business enterprise sector resources. The significance of each variable was evaluated in the same way; i.e. using linear regression and decision trees. The graphical result of linear regression is shown in Figure 3.

Figure 3 shows the visual relationship between the number of patent applications and indirect support. As it can be seen, the linear dependence is visibly weaker than in the Business enterprise sector.

Analogous procedures of the complete model were used to construct the decision tree of the reduced model. The results of the decision tree method are presented in Table 5.

From the results of the reduced model (see Table 5) it is clear that indirect support is the most significant in all tests compared to the remaining variables.

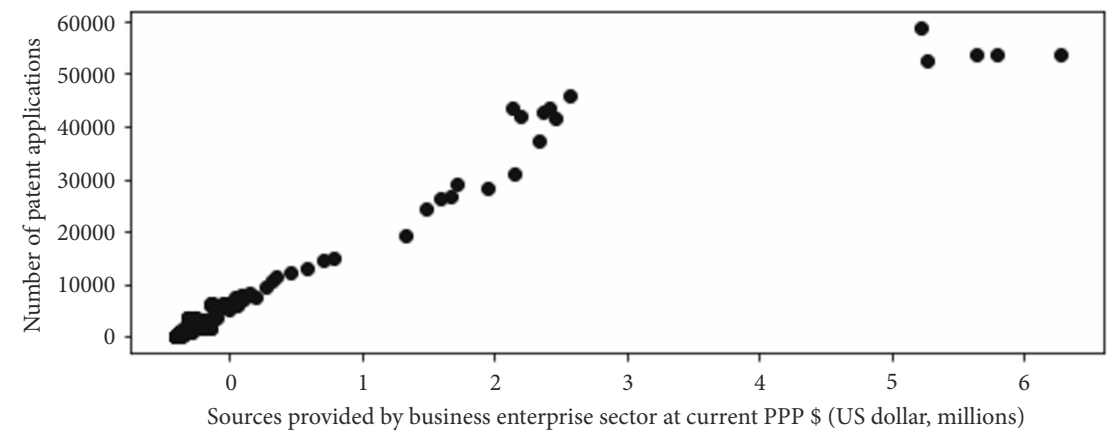

Figure 1. The linear dependence between the number of patent applications and business enterprise sector resources 


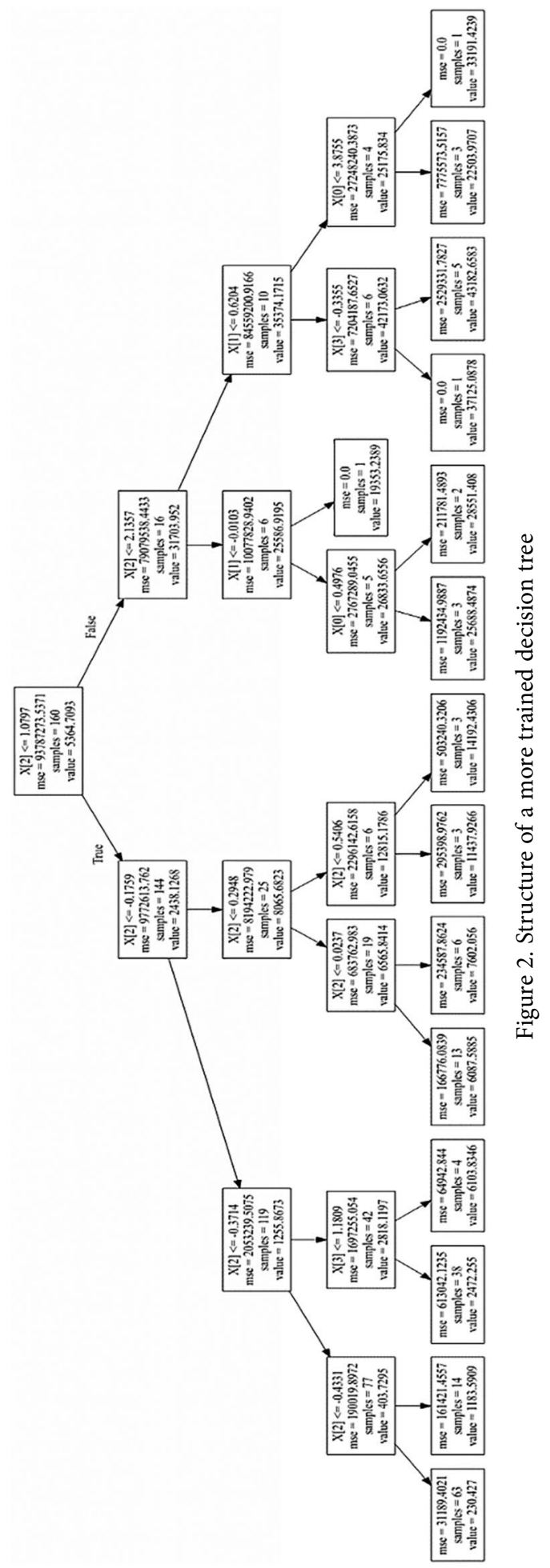




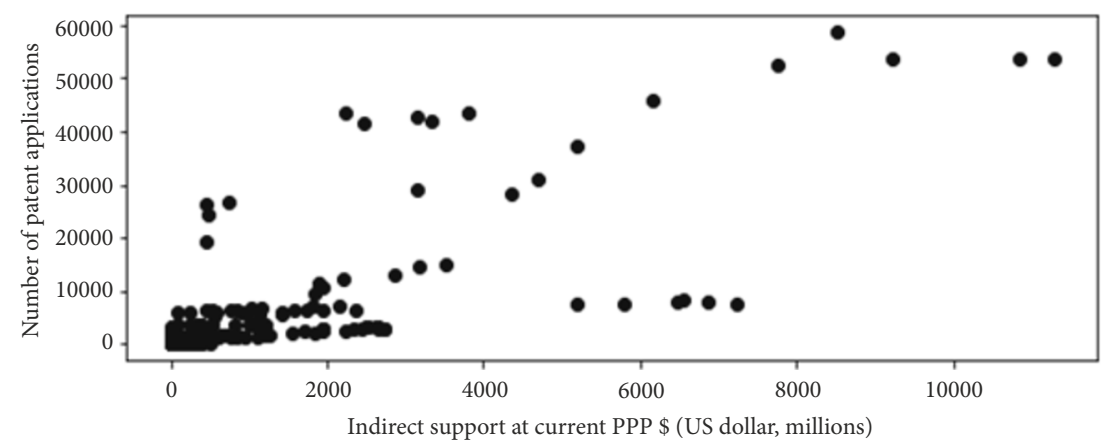

Figure 3. Visual dependence between the number of patent applications and indirect support

Table 5. Decision tree - results of the reduced model (source: author's own; scikit-learn library for Python 3.6; linear_model.linearRegression)

\begin{tabular}{|l|c|c|c|}
\hline Variable & Indirect support & Government sector & Rest of World \\
\hline Feature importance & 0.4373 & 0.3839 & 0.1787 \\
\hline Variable $V_{i}$ & 0.5030 & 0.3535 & 0.1434 \\
\hline
\end{tabular}

Research in the period under review confirms (even after the scaling of variables) for all countries surveyed a significant dependence between the number of patent applications and the financial resources of the Business enterprise sector. The significance of other variables (or sources of funding for R\&D activities) was evaluated in the reduced model in the same way; i.e. using linear regression and decision trees. Of the three variables considered (indirect support, direct support and Rest of World resources), this analysis showed the strongest dependence of the number of patent applications on the amount of indirect support. The significance of the amount of direct support is significantly lower compared to indirect support. The financial resources provided by Rest of World are insignificant in relation to the number of patent applications.

To sum up, the impact of indirect support (or tax incentives) on the volume of relevant $\mathrm{R} \& \mathrm{D}$ outputs is relatively significant. This is largely supported by the relatively easy possibility of receiving this type of support. Indirect support has a wide use, it is relatively administratively simple and every company is highly likely to obtain it if the legal conditions are met. This type of support is attractive for small start-ups and truly innovative companies, for which it is quite problematic to get direct support in the form of a subsidy title in the tough competition of larger companies. Indirect support can also be an interesting tool for high-risk $\mathrm{R} \& \mathrm{D}$ projects with high potential. Due to the high risk, these projects make it hardly possible to obtain external resources. Indirect support is a part of internal corporate resources and is therefore usable for funding R\&D activities regardless of the level of risk. The weaker linear dependence of indirect support and patent applications is due to a number of factors, some of which have been discussed in the literature review. If the conditions for obtaining a specific tax incentive are not set up optimally, or if the management of the use of these incentives does not work effectively enough, the motivation of companies to R\&D activities 
is significantly reduced. Indirect support then serves only as a tool for tax optimization and does not help generate the outputs required by the government's innovation strategies.

Although our study worked with certain limitations defined above, it can be stated that our outputs reflect the current knowledge and experience of researchers from European countries. Current research from various EU countries shows that the setting of direct and indirect $\mathrm{R} \& \mathrm{D}$ support must be done very sensitively. Using both supports at the same time may not bring higher benefits. According to recent research, Dumont's (2019) indirect incentives contribute relatively significantly to stimulating private investment in $R \& D$. It is very difficult to set a R\&D support policy so that it actually leads to the implementation of R\&D projects and does not only serve for tax optimization (Czarnitzki \& Hussinger, 2018). It is necessary to continuously evaluate the effectiveness of these policies (Basto et al., 2021) and to support $\mathrm{R} \& \mathrm{D}$ activities in the corporate sphere by a mix of policy instruments (Nilsen et al., 2020).

\section{Conclusions}

Research, development and innovation have traditionally been important sources of economic growth, improving living standards and competitiveness. Developed countries around the world invest considerable resources in the area of R\&D. To support research activities, each country implements a mix of tools in the economic environment that help realize the goals set by national innovation strategies and accelerate economic growth. Business entities finance $\mathrm{R} \& \mathrm{D}$ activities from their sources or use direct and indirect support instruments. The pros and cons of these subsidies are widely discussed by experts, and their effectiveness is also examined. The carried out research was focused primarily on indirect support. This support is provided in virtually all developed countries in the form of tax incentives, whether in the form of an expense-based incentive, enhanced allowance, or a patent box. The aim of the research was to determine the extent of the effect of indirect support on the volume of R\&D outputs generated by companies using statistical models. The number of patent applications was chosen as a relevant indicator of $\mathrm{R} \& \mathrm{D}$ volume. The research has shown that enterprise resources are the most important generator of R\&D outputs in terms of patent applications. When this variable is eliminated, indirect support is evaluated as a source of $\mathrm{R} \& \mathrm{D}$ funding with the potential of relevant outputs. The findings correspond to the current state of knowledge. From our outputs and the discussion of the current authors, it is clear that if the system of indirect support is optimally implemented in the economic environment and the management of the system works effectively, the indirect support tools show a relatively high potential for supporting research and innovation activities of companies in accordance with the society-wide strategy.

\section{Acknowledgements}

This article was written as one of the outputs of support from the project of Excellent Research called "New Approaches to the Reporting of Intangible Assets in the Czech Republic" that is being continuously implemented at the Faculty of Economics of the Technical University in Liberec within the years 2018-2019. 


\section{References}

Akis, E. (2015). Innovation and competitive power. Procedia - Social and Behavioral Sciences, 195, 1311-1320. https://doi.org/10.1016/j.sbspro.2015.06.304

Basto, R. B., Martins, A., \& Nogueira, G. (2021). The impact of R\&D tax incentives in Portugal (GEE Papers No. 0158). Gabinete de Estratégia e Estudos, Ministério da Economia.

Bernanke, C. B. S. (2011, May 16). Promoting research and development: the government's role [Conference presentation]. Board of Governors of the Federal Reserve System at the Conference on New Building Blocks for Jobs and Economic Growth, Washington.

Bloom, N., Schankerman, M., \& van Reenen, J. (2013). Identifying technology spillovers and product market Rivalry. Econometrica, 81(4), 1347-1393. https://doi.org/10.3982/ECTA9466

Bronzini, R., \& Iachini, E. (2014). Are incentives for R\&D effective? Evidence from a regression discontinuity approach. American Economic Journal: Economic Policy, 6(4), 100-134. https://doi.org/10.1257/pol.6.4.100

Calvino, F., Criscuolo, C., \& Menon, C. (2016). No country for young firms?: Start-up dynamics and national policies (OECD Science, Technology and Industry Policy Papers No. 29). OECD Publishing.

Carboni, O. A. (2011). R\&D subsidies and private R\&D expenditures: evidence from Italian manufacturing data. International Review of Applied Economics, 25(4), 419-439.

https://doi.org/10.1080/02692171.2010.529427

Castellacci, F., \& Lie, C. M. (2015). Do the effects of R\&D tax credits vary across industries? A metaregression analysis. Research Policy, 44(4), 819-832. https://doi.org/10.1016/j.respol.2015.01.010

Czarnitzki, D., \& Hussinger, K. (2018). Input and output additionality of R\&D subsidies. Applied Economics, 50(12), 1324-1341. https://doi.org/10.1080/00036846.2017.1361010

Czech Statistical Office. (2019, January 25). Ukazatele VaV za podnikatelský sektor. https://www.czso. $\mathrm{cz} / \mathrm{csu} / \mathrm{czso} / 2$-ukazatele-vav-za-podnikatelsky-sektor-c7jv4q1teh

de Rassenfosse, G., \& van Pottelsberghe de la Potterie, B. (2011). On the price elasticity of demand for patents. Oxford Bulletin of Economics and Statistics, 74(1), 58-77.

https://doi.org/10.1111/j.1468-0084.2011.00638.x

Deloitte. (2018). Tax and subsidy support for research and development activities: Evaluation of the survey in the Czech Republic. https://www2.deloitte.com/cz/cs/pages/about-deloitte/articles/ce-corporateresearch-development-report.html

Drabkova, Z. (2017). CFEBT risk triangle of accounting errors and frauds - analytical tool of fraud risk management and reduction of information asymmetry between creators and users of accounting reports. In I. Jindrichovska \& D. Kubickova, IFRS: global rules and local use (pp. 286-299). AngloAmerican University.

Dumont, M. (2019). Tax incentives for business R\&D in Belgium - Third evaluation (Working Papers No. 04-19). Federal Planning Bureau, Belgium.

Edler, J., Berger, M., Dinges, M., \& Gök, A. (2012). The practice of evaluation in innovation policy in Europe. Educational Research and Evaluation, 21(3), 167-182.

https://doi.org/10.1093/reseval/rvs014

Einiö, E. (2014). R\&D subsidies and company performance: Evidence from geographic variation in government funding based on the ERDF population-density rule. Review of Economics and Statistics, 96(4), 710-728. https://doi.org/10.1162/REST_a_00410

Ernst, C., \& Spengel, C. (2011). Taxation, $R \& D$ tax incentives and patent application in Europe (ZEW Discussion Papers No. 11-024). ZEW. https://doi.org/10.2139/ssrn.1805762

Ernst, C., Richter, K., \& Riedel, N. (2014). Corporate taxation and the quality of research and development. International Tax and Public Finance, 21(4), 694-719.

https://doi.org/10.1007/s10797-014-9315-2 
European Union. (2012). Commission Implementing Regulation (EU) No 995/2012 of 26 October 2012 laying down detailed rules for the implementation of Decision No 1608/2003/EC of the European Parliament and of the Council concerning the production and development of Community statistics on science and technology. https://eur-lex.europa.eu/legal-content/EN/TXT/?uri=CELEX\%3A32012R0995

European Union. (2014). Commission Regulation (EU) No 651/2014 of 17 June 2014 declaring certain categories of aid compatible with the internal market in application of Articles 107 and 108 of the Treaty. https://eur-lex.europa.eu/legal-content/EN/TXT/PDF/?uri=CELEX:32014R0651\&from=CS

Eurostat. (2019, March 10). First estimates of Research \& Development expenditure R\&D expenditure in the EU increased slightly to 2.07\% of GDP in 2017: Two thirds spent inthebusiness enterprise sector. Eurostat Press Office. https://ec.europa.eu/eurostat/documents/2995521/9483597/9-10012019-APEN.pdf/856ce1d3-b8a8-4fa6-bf00-a8ded6dd1cc1

Griffith, R., Miller, H., \& Oconnell, M. (2014). Ownership of intellectual property and corporate taxation. Journal of Public Economics, 112, 12-23. https://doi.org/10.1016/j.jpubeco.2014.01.009

Griliches, Z. (2000). R\&D, education, and productivity: a retrospective. Harvard University Press.

Guellec, D., \& van Pottelsberghe de la Potterie, B. (2003). The impact of public R\&D expenditure on business R\&D*. Economics of Innovation and New Technology, 12(3), 225-243. https://doi.org/10.1080/10438590290004555

Income Tax Act. (1992). Act No. 586/1992 Coll., on Income Taxes, as amended. Czech Republic. https://www.mfcr.cz/

Klemens, B. (2016). A Boxing Match: Can intellectual property boxes achieve their stated goals? U.S. Department of the Treasury, Office of Tax Analysis. https://doi.org/10.2139/ssrn.2822575

Köhler, C., Laredo, P., \& Ramme, R. (2012). The impact and effectiveness of fiscal incentives for R\&D. (Nesta Working Paper No. 12/01). https://doi.org/10.22163/fteval.2012.91

Lokshin, B., \& Mohnen, P. (2013). Do R\&D tax incentives lead to higher wages for R\&D workers? Evidence from The Netherlands. Research Policy, 42(3), 823-830. https://doi.org/10.1016/j.respol.2012.12.004

Lundvall, B. A., \& Borrás, S. (2009). Science technology and inovation policy. In The Oxford handbook of innovation. Oxford University Press.

Ministry of Regional Development of the Czech Republic. (2018, December 10). Metodické doporučení pro oblast veřejné podpory. https://www.dotaceeu.cz/getmedia/a3fdbcee-45a7-440e-a891dc21381b2b04/MD-verejna-podpora_v2.pdf.aspx?ext=.pdf

Nauwelaers, C. (2016). Public research and innovation policies and investment and their evolution since the crisis. In Science, research and innovation performance of the EU: A contribution to the open innovation, open science, open to the world agenda. European Commisison.

Nelson, R. (1959). The simple economics of basic scientific research. Journal of Political Economy, 67(3), 297-306. https://doi.org/10.1086/258177

Neubig, T., Galindo-Rueda, F., \& Appelt, S. (2016). Fiscal incentives for $R \& D$ and innovation in a diverse world (OECD Taxation Working Papers No. 27). OECD Publishing.

Nilsen, Ø. A., Raknerud, A., \& Iancu, D.-C. (2020). Public R\&D support and firm performance: A multivariate dose-response analysis. Research Policy, 49(7), 104067. https://doi.org/10.1016/j.respol.2020.104067

Ognyanova, D. (2017, September). R\&D tax incentives: How to make them most effective? (Working Paper). European Commission.

Pfeiffer, O., \& Spengel, C. (2017). Tax incentives for research and development and their use in tax planning (ZEW Discussion Paper No. 17-046). ZEW. https://doi.org/10.2139/ssrn.3067926 
Pisár, P., Duurčeková, I., \& Stachová, M. (2020). The contribution of innovation actors into business R\&D funding - does the substitution effect of public support work in the EU? E\&M Economics and Management, 23(1), 121-134. https://doi.org/10.15240/tul/001/2020-1-009

Schumpeter, J. A. (1934). The Theory of economic development: an inquiry into profits, capital, credit, interest, and the business cycle. Harvard University Press.

Schumpeter, J. A. (1954). History of economic analysis. Oxford University Press.

Skeie, Ø. B., Johansson, A., Menon, C., \& Sorbe, S. (2017). Innovation, patent location and tax planning by multinationals (OECD Economics Department Working Papers No. 1360). OECD Publishing.

Technology Agency of the Czech Republic. (2019, September 2). Analýza patentů českých původců dle jejich vlastnictví. TAČR. https://www.google.com/url? sa=t\&rct=j\&q=\&esrc=s\&source=web\&cd=1\& ved=2ahUKEwivvcXknvbkAhVwU98KHW1sBd4QFjAAegQIABAC\&url=https\%3A\%2F\%2Fwww. tacr.cz\%2Fdokums_raw\%2Fnovinky\%2F190822_patenty_podle_typu_vlastnictvi.pdf\&usg=AOvVa w3UE74RGCQNGNx8quir4v2N

The Organisation for Economic Co-operation and Development. (2009). OECD patent statistics manual. OECD Publishing. https://doi.org/10.1787/9789264056442-en

The Organisation for Economic Co-operation and Development. (2013). Definition, interpretation and calculation of the B index. OECD Publishing. https://www.oecd.org/sti/b-index.pdf

The Organisation for Economic Co-operation and Development. (2015). Frascati manual 2015: guidelines for collecting and reporting data on research and experimental development (Series: The Measurement of Scientific, Technological and Innovation Activities). OECD Publishing.

Toledano, P., Johnson, L., Sachs, L. E., \& Tavares, T. (2016). Rethinking investment incentives: trends and policy options. Columbia University Press. https://doi.org/10.7312/columbia/9780231172981.003.0012

Warda, J. (2001). Measuring the value of R\&D tax treatment in OECD countries. In OECD STI review No. 27. Special issue on new science and technology indicators (pp. 185-211). OECD Publishing.

Westmore, B. (2013). $R \& D$, patenting and growth: the role of public policy (OECD Economics Department Working Papers No. 1047). OECD Publishing. 